\title{
Biogeochemical indicators of peatland degradation - a case study of a temperate bog in northern Germany
}

\author{
J. P. Krüger ${ }^{1}$, J. Leifeld ${ }^{2}$, S. Glatzel ${ }^{3}$, S. Szidat ${ }^{4}$, and C. Alewell ${ }^{1}$ \\ ${ }^{1}$ Environmental Geosciences, University of Basel, Bernoullistrasse 30, 4056 Basel, Switzerland \\ ${ }^{2}$ Air Pollution/Climate Group, Agroscope Reckenholz-Tänikon ART, Reckenholzstrasse 191, 8046 Zürich, Switzerland \\ ${ }^{3}$ Department of Geography and Regional Research - Geoecology, University of Vienna, Althanstrasse 14, \\ 1090 Vienna, Austria \\ ${ }^{4}$ Department of Chemistry and Biochemistry \& Oeschger Centre for Climate Change Research, University of Bern, \\ Freiestrasse 3, 3012 Bern, Switzerland
}

Correspondence to: J. P. Krüger (janpaul.krueger@unibas.ch)

Received: 1 October 2014 - Published in Biogeosciences Discuss.: 9 December 2014

Revised: 9 April 2015 - Accepted: 18 April 2015 - Published: 19 May 2015

\begin{abstract}
Organic soils in peatlands store a great proportion of the global soil carbon pool and can lose carbon via the atmosphere due to degradation. In Germany, most of the greenhouse gas (GHG) emissions from organic soils are attributed to sites managed as grassland. Here, we investigated a land use gradient from near-natural wetland (NW) to an extensively managed (GE) to an intensively managed grassland site (GI), all formed in the same bog complex in northern Germany. Vertical depth profiles of $\delta^{13} \mathrm{C}, \delta^{15} \mathrm{~N}$, ash content, $\mathrm{C} / \mathrm{N}$ ratio and bulk density as well as radiocarbon ages were studied to identify peat degradation and to calculate carbon loss. At all sites, including the near-natural site, $\delta^{13} \mathrm{C}$ depth profiles indicate aerobic decomposition in the upper horizons. Depth profiles of $\delta^{15} \mathrm{~N}$ differed significantly between sites with increasing $\delta^{15} \mathrm{~N}$ values in the top soil layers paralleling an increase in land use intensity owing to differences in peat decomposition and fertilizer application. At both grassland sites, the ash content peaked within the first centimetres. In the near-natural site, ash contents were highest in $10-60 \mathrm{~cm}$ depth. The ash profiles, not only at the managed grassland sites, but also at the near-natural site indicate that all sites were influenced by anthropogenic activities either currently or in the past, most likely due to drainage. Based on the enrichment of ash content and changes in bulk density, we calculated the total carbon loss from the sites since the peatland was influenced by anthropogenic activities. Carbon loss at the sites increased in the following order: NW $<\mathrm{GE}<\mathrm{GI}$. Radiocarbon ages of peat in the topsoil of GE and GI were
\end{abstract}

hundreds of years, indicating the loss of younger peat material. In contrast, peat in the first centimetres of the NW was only a few decades old, indicating recent peat growth. It is likely that the NW site accumulates carbon today but was perturbed by anthropogenic activities in the past. Together, all biogeochemical parameters indicate a degradation of peat due to (i) conversion to grassland with historical drainage and (ii) land use intensification.

\section{Introduction}

Peatlands comprise the most important soil organic carbon (C) pool, storing more than $600 \mathrm{PgC}$ (Yu et al., 2011; Jungkunst et al., 2012). In these water-saturated soils, anoxic conditions hinder organic-matter decomposition and favour peat accumulation (Clymo, 1984). Drainage of peatlands induces oxic conditions and causes increasing carbon dioxide emissions (Maljanen et al., 2001) resulting in a net loss of carbon to the atmosphere. Over the last century, more than $50 \%$ of the peatland area in Europe has been converted mainly to agriculture or forestry (Byrne et al., 2004). In Germany, $75 \%$ of the greenhouse gas (GHG) emissions from organic soils are attributed to agricultural use (Höper, 2007) and more than half of the GHG emissions from managed peatlands originate from grassland sites (Drösler et al., 2008). Together, GHGs from organic soils comprise $5.1 \%$ of Germany's national total emissions (Drösler et al., 2013). 
In the temperate zone GHG emissions from peatlands under grassland use average $0.6 \mathrm{~kg} \mathrm{C} \mathrm{m}^{-2} \mathrm{yr}^{-1}$ for deeply drained and $0.4 \mathrm{~kg} \mathrm{C} \mathrm{m}^{-2} \mathrm{yr}^{-1}$ for shallowly drained peatlands (IPCC, 2013). Ranked by land use intensity, intensively managed grasslands emit $2.8 \mathrm{~kg} \mathrm{CO}_{2 \mathrm{eq}} \mathrm{m}^{-2} \mathrm{yr}^{-1}$ and extensively managed grasslands emit between 0.2 and $2.0 \mathrm{~kg} \mathrm{CO}_{2 \mathrm{eq}} \mathrm{m}^{-2} \mathrm{yr}^{-1}$ (depending on the water table) (Drösler et al., 2013). Near-natural bogs are almost climateneutral, but dry bogs emit up to $1.0 \mathrm{kgCO}_{2 \mathrm{eq}} \mathrm{m}^{-2} \mathrm{yr}^{-1}$ (Drösler et al., 2013).

To study soil degradation in different environments, stable carbon and nitrogen isotopes are a useful tool (Schaub and Alewell, 2009; Alewell et al., 2011; Conen et al., 2013; Meusburger et al., 2013; Krüger et al., 2014). In two recent studies in the subarctic region, stable carbon isotope depth profiles were shown to be a meaningful indicator of peatland degradation as well as of the uplifting by permafrost (Alewell et al., 2011; Krüger et al., 2014).

In a natural peatland with low decomposition rates, the $\delta^{13} \mathrm{C}$ signature is almost constant with depth because in water-saturated soils the oxygen availability is low, decomposition of organic material is reduced and therefore isotopic fractionation is small (Clymo and Bryant, 2008; Skrzypek et al., 2008; Alewell et al., 2011). However, under conditions of anaerobic decomposition, $\delta^{13} \mathrm{C}$ may slightly decrease with depth because substances such as lignin, which require aerobic conditions for their decomposition, are relatively enriched in ${ }^{13} \mathrm{C}$ (Benner et al., 1987; Alewell et al., 2011). Under aerobic conditions, decomposers preferentially use the lighter ${ }^{12} \mathrm{C}$ for respiration. Hence, the heavier ${ }^{13} \mathrm{C}$ accumulates in the remaining organic matter and the $\delta^{13} \mathrm{C}$ value increases with depth (Nadelhoffer and Fry, 1988; Ågren et al., 1996). Increasing $\delta^{13} \mathrm{C}$ values with depth are typical for welldrained or mineral soils (Nadelhoffer and Fry, 1988; Alewell et al., 2011). With a switch from anaerobic to aerobic conditions, peatland drainage is suggested to induce a change from a uniform $\delta^{13} \mathrm{C}$ depth profile to increasing $\delta^{13} \mathrm{C}$ values with depth (Fig. 1).

Because atmospheric $\mathrm{N}$ is the primary source of $\mathrm{N}$ in a natural terrestrial ecosystem, $\delta^{15} \mathrm{~N}$ values in bogs are assumed to scatter around 0\%o (Fig. 1; Jones et al., 2010; Broder et al., 2012). However, plant species in intact peatlands vary substantially in their $\delta^{15} \mathrm{~N}$ signature from -11.3 to $+2.7 \%$ o (Asada et al., 2005b), which could influence the $\delta^{15} \mathrm{~N}$ signature of the remaining peat material. A second source of variability comes from nitrogen isotope fractionation during decomposition, leading to an enrichment of ${ }^{15} \mathrm{~N}$ in the remaining material and an increase in soil ${ }^{15} \mathrm{~N}$ with depth and age (Nadelhoffer and Fry, 1988; Nadelhoffer et al., 1996). Therefore, $\delta^{15} \mathrm{~N}$ values in oxic soils increase with depth (Fig. 1; Nadelhoffer et al., 1996; Kohzu et al., 2003). We hypothesize that in drained and/or degraded peatlands, too, owing the above-mentioned processes, $\delta^{15} \mathrm{~N}$ values increase with depth (Fig. 1). In intensively managed ecosystems, the application of mineral and/or organic fertilizer, with their different iso-

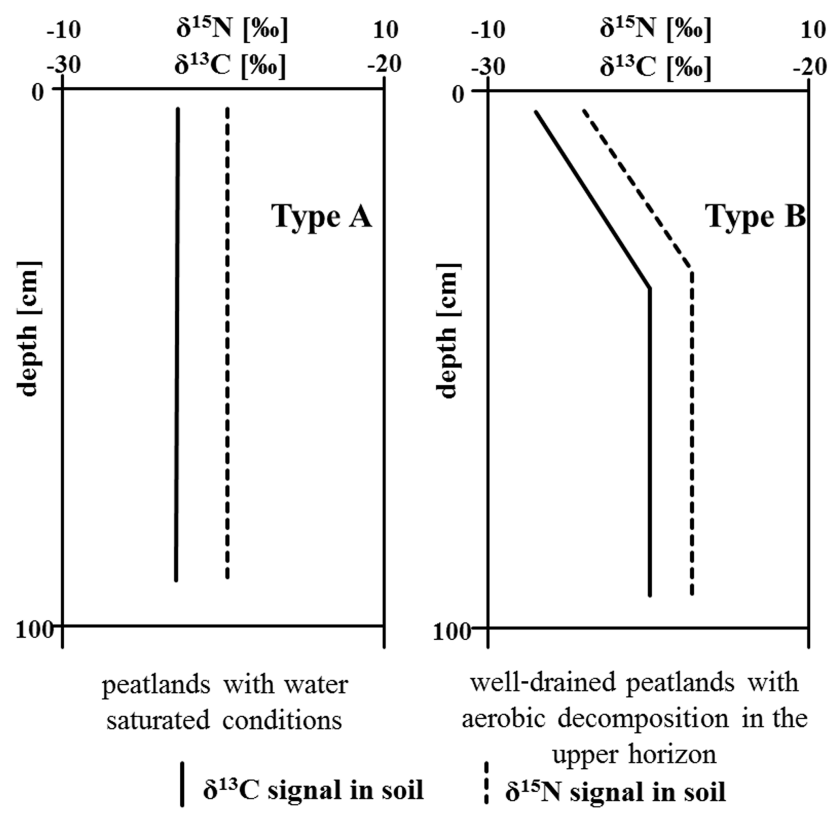

Figure 1. Theoretical concept of $\delta^{13} \mathrm{C}$ and $\delta^{15} \mathrm{~N}$ depth profiles in natural (left) and degraded (right) peatlands.

topic signals (Bateman and Kelly, 2007), additionally alters the stable nitrogen isotope signature in soil.

In natural peat profiles the radiocarbon signature shows an increasing age with depth (Shotyk et al., 1998) due to peat accumulation in the course of time. Owing to the loss of peat which has been accumulated in the last several hundreds or thousands of years, a degrading peatland, with a loss of the younger, more recently accumulated $\mathrm{C}$ of the upper layers to the atmosphere, changes the ${ }^{14} \mathrm{C}$ depth profile towards higher ages near the peat surface.

The $\mathrm{C} / \mathrm{N}$ ratio indicates the degree of the decomposition of the peat material (Malmer and Holm, 1984; Kuhry and Vitt, 1996). Peat that is only decomposed a little has larger $\mathrm{C} / \mathrm{N}$ ratios, reflecting the former plant material, whereas the ratio becomes smaller in strongly decomposed peat owing to a preferential loss of $\mathrm{C}$ over $\mathrm{N}$ during microbial decomposition.

A simple but reliable estimate of C loss from cultivated peatlands can be obtained based on differences in ash content throughout the peat profile (Grønlund et al., 2008; Rogiers et al., 2008; Leifeld et al., 2011a). These methods are based on the premise of the accumulation of mineral matter (or "ash") with peat oxidation, i.e. preferential loss of organic vs. mineral matter. In a pristine state of a bog, where mineral input solely derives from the atmosphere, we assume a relatively homogeneous ash depth profile. Drainage induces peat oxidation and net $\mathrm{CO}_{2}$ emission, leading to peat subsidence and a relative enrichment of ash content in the upper layers, where decomposition is strongest. A so-called combined method (Leifeld et al., 2014) makes use of differences in bulk density and ash content in the profile in order to estimate 
not only $\mathrm{C}$ loss but also volumetric changes in the peat. It distinguishes between primary (settling) and secondary (oxidation) subsidence of the peat after drainage (Ewing and Vepraskas, 2006).

The main goal of our study was to test whether stable isotopes of carbon and nitrogen can be used as indicators of peatland degradation along a gradient of land use and drainage intensity and whether we could estimate carbon loss a posteriori. We apply the above concepts to a typical and well-studied peatland complex, the Ahlen-Falkenberger peatland, in northern Germany. Our hypotheses are as follows:

I. The $\delta^{13} \mathrm{C}$ depth profile changes from a constant signal under near-natural conditions to increasing $\delta^{13} \mathrm{C}$ values with depth in degrading peatlands.

II. Higher decomposition of the peat in the degraded sites leads to an enrichment of ${ }^{15} \mathrm{~N}$ values in the upper layers.

III. C losses are higher in the intensively managed compared to the extensively managed grassland.

Analysis of other indicators, such as radiocarbon age, ash content and $\mathrm{C} / \mathrm{N}$ ratio, will be used for the validation of the interpretation of the stable isotope depth profiles.

\section{Materials and methods}

\subsection{Site description}

The study area is located in Lower Saxony, north-western Germany, close to the North Sea coast. The peat bog complex called Ahlen-Falkenberger peatland $\left(53^{\circ} 41^{\prime} \mathrm{N}, 8^{\circ} 49^{\prime} \mathrm{E}\right)$ is one of the largest peat bog complexes in northern Germany. The climate is humid Atlantic, with a mean annual precipitation of $925.7 \mathrm{~mm}$ and a mean annual temperature of $8.5^{\circ} \mathrm{C}$ (reference period 1961-1990; German Weather Service, 2010). Bog formation began at about 6000 years BP on a former fen area (Schneekloth, 1970). From the late 17 th century onwards, peat was extracted at the edges of the bog. Drainage activities started at the beginning of the 20th century. In the middle of the 20th century, over 50 homesteads were established in the Ahlen-Falkenberger peatland and land use was intensified (Ahrendt, 2012). Industrial peat extraction at the Ahlen-Falkenberger peatland began in 1957 (Schneekloth, 1981) and was terminated in the 1990s, when a conservation area was established (Beckmann and Krahn, 1991; Beller et al., 1994). About $60 \%$ of the remaining former bog is currently used as grassland, and only a small area in the centre of the peat bog complex (approx. $5 \%$ ) was never drained or cultivated and remains as a natural peat bog today (Höper, 2007). In this area, vegetation is dominated by cross-leaved heath (Erica tetralix L.), flat-topped bog moss (Sphagnum fallax (Klinggr.)) and common cotton grass
(Eriophorum angustifolium Honck.). We consider this nearnatural wetland (NW) to be unmanaged. Further, we studied two areas of the former bog which are drained and today are managed as grassland: the extensive grassland (GE) is neither fertilized nor manured and only cut once per year; the intensive grassland (GI) is cut four to five times per year and fertilized with mineral fertilizer and manure (see details for the years 2008/2009 in Beetz et al., 2013). Liming and cattle grazing was never performed on these sites. GI is drained by pipes as well as drainage ditches, whereas GE is only drained by ditches, which were closed in 2003/2004. At the NW site, the water table was around the soil surface with a variation of -10 to $5 \mathrm{~cm}$ in 2012 and fluctuated between the surface and $40 \mathrm{~cm}$ depth (GE) and between the surface and $80 \mathrm{~cm}$ depth (GI; Frank et al., 2014). Across the former bog complex, peat thicknesses range from $330 \mathrm{~cm}$ in cultivated to $515 \mathrm{~cm}$ in uncultivated, near-natural areas (Beetz et al., 2013). Recent GHG flux measurements at the Ahlen-Falkenberger peatland (July 2007- June 2009) indicate that site NW was C neutral in one year $\left(-0.002 \mathrm{~kg} \mathrm{C} \mathrm{m}^{-2} \mathrm{yr}^{-1}\right)$ and accumulated $\mathrm{C}$ in the next year $\left(-0.124 \mathrm{~kg} \mathrm{C} \mathrm{m}^{-2} \mathrm{yr}^{-1}\right.$; Beetz et al., 2013). The net ecosystem carbon balance at site GE was positive in one $\left(0.088 \mathrm{~kg} \mathrm{C} \mathrm{m}^{-2} \mathrm{yr}^{-1}\right)$ and negative in the following year $\left(-0.147 \mathrm{~kg} \mathrm{C} \mathrm{m}^{-2} \mathrm{yr}^{-1}\right.$; Beetz et al., 2013). GI was a carbon source for both years with $\mathrm{C}$ loss of about 0.548 to $0.817 \mathrm{~kg} \mathrm{C} \mathrm{m}^{-2} \mathrm{yr}^{-1}$ (Beetz et al., 2013).

\subsection{Soil sampling and analyses}

In November 2012, three peat cores per site were collected in the Ahlen-Falkenberger peatland at NW, GE and GI $(n=3)$ (Fig. S1 in the Supplement). We took our cores close to the same locations from earlier studies by Beetz et al. (2013) and Frank et al. (2014). Peat samples were taken in the first $50 \mathrm{~cm}$ with a soil corer (Giddings Machine Company, US) and in deeper parts with a Russian peat corer (Eijkelkamp, Netherlands) down to approximately $1 \mathrm{~m}$. Cores were embedded in plastic shells, wrapped with plastic foil and transported directly to the lab. Cores were cut into $2 \mathrm{~cm}$ sections and ovendried at $40-50^{\circ} \mathrm{C}$ for $72 \mathrm{~h}$. All samples were ground and homogenized in a vibrating ball mill (MM 400, Retsch, Germany). Stable carbon and stable nitrogen isotopes as well as $\mathrm{C}$ and $\mathrm{N}$ content were measured by combined mass spectrometry coupled to an SL elemental analyser (Integra2, Sercon, UK). The $\mathrm{C} / \mathrm{N}$ ratio represents the mass relationship between the carbon and nitrogen content of the bulk peat material. Stable carbon isotope ratios are reported as $\delta^{13} \mathrm{C}$ in per mill relative to the VPDB standard. Stable nitrogen isotope ratios are reported as $\delta^{15} \mathrm{~N}$ in per mill relative to the atmospheric nitrogen standard. The analytical standard deviation is 0.15 and $0.1 \%$ for $\delta^{15} \mathrm{~N}$ and $\delta^{13} \mathrm{C}$, respectively.

The ash content was determined by thermogravimetry (prepAsh, Precia, Switzerland), using 0.5-1.0 g sample material. Pre-drying at $130{ }^{\circ} \mathrm{C}$ was carried out to correct the dry mass and to evaporate the residual moisture. The sample was 
then heated to $600^{\circ} \mathrm{C}$ in air until no significant mass change (constant mass) could be measured (see detailed description of the method by Leifeld et al., 2011a). The material remaining after heating is defined as the ash content of the sample.

\subsection{Radiocarbon analyses}

Radiocarbon $\left({ }^{14} \mathrm{C}\right)$ analysis was performed with accelerator mass spectrometry (AMS) at the Laboratory for the Analysis of Radiocarbon with AMS (LARA) at the University of Bern (Szidat et al., 2014). At each site, three depths were selected for radiocarbon dating, and the ${ }^{14} \mathrm{C}$ content of samples from these depths was measured for each individual core. Samples were selected after the evaluation of stable isotope and ash content depth profiles. Segments where stable isotope and ash contents clearly changed were selected for radiocarbon analysis. The ground and homogenized material was combusted, transformed into solid targets using automated graphitization equipment (AGE; Nemec et al., 2010) and measured with the MIni CArbon DAting System MICADAS (Synal et al., 2007). Sample homogeneity and measurement reproducibility was proven by the double analysis of eight random samples, and general accuracy and precision had been reported earlier (Szidat et al., 2014). ${ }^{14} \mathrm{C}$ ages were calibrated using the IntCal13 data set (Reimer et al., 2013). Samples with bomb signature were dated using the Bomb13 NH1 data set (Hua et al., 2013). Radiocarbon ages are presented for each site and selected depth are given as means $(n=3)$ with $1 \mathrm{SD}$ in cal years $\mathrm{AD}$ or cal years BC. Results of the individual measurements are shown in Table S1 in the Supplement.

\subsection{Calculation of carbon loss by the ash content and bulk density (combined method)}

The integrated calculation of carbon loss of the peatland since the beginning of drainage is based on the simplified assumption that the ratio between carbon and ash content during the accumulation of peat is constant and that ash content before drainage is the same at all depths. After drainage, peat starts to oxidize and carbon is lost as $\mathrm{CO}_{2}$ (Rogiers et al., 2008). Additionally, we assume that the ash content in the deeper parts of the profile is not affected by drainage. Ash from the oxidized peat remains at the site and accumulates in the upper layer of the profile. Differences in soil properties of bulk density, ash content and organic $\mathrm{C}$ content between the topsoil and undisturbed subsoil can be used to infer predrainage soil thickness and $\mathrm{C}$ stocks. The mean ash content of the deeper parts of the profiles, where samples show no enrichment of ash, in our case below $80 \mathrm{~cm}$ depth, of each individual core was taken as a reference value (Leifeld et al., 2011a). The $\mathrm{C}$ loss was calculated separately for each core.

The method of Leifeld et al. (2014) combines two previously published methods which were based on changes in bulk density (Leifeld et al., 2011b) and changes in ash con- tent (Rogiers et al., 2008; Leifeld et al., 2011a) in peat profiles. This so-called combined method (Leifeld et al., 2014) estimates the physical primary subsidence due to the loss of pore water and peat shrinkage and estimates the chemical secondary subsidence due to the oxidative loss of organic matter.

The primary subsidence $S_{\mathrm{p}}(\mathrm{m})$ is calculated as follows (Leifeld et al., 2014):

$S_{\mathrm{P}}=\mathrm{PT}_{0 i}-\mathrm{PT}_{i}$,

with

$\mathrm{PT}_{0 i}=\mathrm{Bd}_{\mathrm{OS} i} / \mathrm{Bd}_{\mathrm{OS} r} \cdot \mathrm{PT}_{i}$,

where $\mathrm{PT}_{0 i}$ is the pre-drainage thickness of layer $i(\mathrm{~m})$, $\mathrm{Bd}_{\mathrm{OS} i}$ is the organic-matter density in layer $i, \mathrm{Bd}_{\mathrm{OS} r}$ is organic-matter density of the reference layer $\left(\mathrm{g} \mathrm{cm}^{-3}\right)$ and $\mathrm{PT}_{i}$ is the thickness of layer $i(\mathrm{~m})$ at the time of sampling. $\mathrm{Bd}_{\mathrm{OS}}$ is calculated from the soil mass of per unit soil volume minus the ash mass and the ash volume of the same soil volume, assuming a specific density of ash particles of $2.65 \mathrm{~g} \mathrm{~cm}^{-3}$.

The secondary subsidence $S_{\mathrm{s}}$ is calculated from the predrainage thickness $\mathrm{ST}_{0 i}(\mathrm{~m})$ attributable to organic-matter oxidation (Leifeld et al., 2014):

$\mathrm{ST}_{0 i}=\mathrm{ST}_{i} \cdot F_{\text {ashi }} / F_{\text {ashr }}$,

with $\mathrm{ST}_{i}$ being the thickness of layer $i(\mathrm{~m}), F_{\mathrm{ash}} i$ the ash concentration of layer $i$ and $F_{\text {ashr }}$ the ash concentration of the reference layer.

$S_{\mathrm{s}}=\mathrm{ST}_{0 i}-\mathrm{ST}_{i}$

Before drainage, any layer $\mathrm{ST}_{0 i}$ contained the same amount of carbon per soil volume as the contemporary undisturbed reference layers $\mathrm{ST}_{\mathrm{r}}$ in the deeper soil profile. The amount of soil carbon in any single layer $\mathrm{C}_{\mathrm{d} i}\left(\mathrm{~kg} \mathrm{~m}^{-2}\right)$ lost by oxidation is given as

$\mathrm{C}_{\mathrm{d} i}=S_{\mathrm{s}} \cdot \mathrm{C}_{\mathrm{r}} / \mathrm{ST}_{\mathrm{r}}$,

with $\mathrm{C}_{\mathrm{r}}$ being the soil carbon stock of the reference layer $\left(\mathrm{kg} \mathrm{m}^{-2}\right), \mathrm{ST}_{\mathrm{r}}$ the thickness of the reference layer $(\mathrm{m})$ and $S_{\mathrm{S}}(\mathrm{m})$ the volumetric loss due to peat oxidation. Beside the carbon loss, total peat subsidence $(\mathrm{m})$ can be calculated by the combined method. Carbon losses since the peatland was drained are displayed as $\mathrm{kg} \mathrm{C} \mathrm{m}^{-2}$.

The NW site could not be taken as a reference for the calculation of $\mathrm{C}$ loss for the managed sites because it was also influenced by drainage activities in surrounding areas as indicated by higher ash contents at $10-50 \mathrm{~cm}$ depth. We instead used the deeper layers (samples below $80 \mathrm{~cm}$ depth) of the grassland sites as a reference, similar to the approach taken in previous studies (Rogiers et al., 2008; Leifeld et al., 2011a). 


\subsection{Statistical analyses}

Spearman correlation analyses were used to identify the relationship between $\delta^{13} \mathrm{C}, \delta^{15} \mathrm{~N}$ and $\mathrm{C} / \mathrm{N}$. Regression analysis of $\delta^{13} \mathrm{C}$ and depth was carried out with the software R2.15.1. At each individual core, $\delta^{13} \mathrm{C}$ values against depth were used from the uppermost sample down until $\delta^{13} \mathrm{C}$ reached a value below $-25.0 \%$.

\section{Results and discussion}

\subsection{Stable carbon isotopes}

In both grassland soils, $\delta^{13} \mathrm{C}$ values increase from about $-30.0 \%$ in the upper centimetres to about $-25.0 \%$ in deeper layers (Fig. 2b, c). This increase in $\delta^{13} \mathrm{C}$ values with depth indicates aerobic conditions in the peat profile, as aerobic decomposers selectively used the lighter isotope ${ }^{12} \mathrm{C}$ for respiration, whereas the heavier ${ }^{13} \mathrm{C}$ is enriched in the remaining organic material of the soil (Nadelhoffer and Fry, 1988; Ågren et al., 1996). This $\delta^{13} \mathrm{C}$ depth pattern was also found at site NW, indicating aerobic degradation (Fig. 2a). In general, natural peatlands are expected to show a uniform $\delta^{13} \mathrm{C}$ depth profile (Clymo and Bryant, 2008; Skrzypek et al., 2008 ) or a trend towards slightly lower values, caused by an enrichment of recalcitrant substances depleted in ${ }^{13} \mathrm{C}$ (Benner et al., 1987; Krull and Retallack, 2000; Alewell et al., 2011). The Suess effect could have contributed to the low $\delta^{13} \mathrm{C}$ values in the uppermost layer of the near-natural site, but the further increase in $\delta^{13} \mathrm{C}$ with depth is connected to peat material much older than the Suess effect and is very likely owing to aerobic decomposition of the peat. An increase in $\delta^{13} \mathrm{C}$ values with depth by about 4.0 to $5.0 \%$ is typical for well-drained mineral soils (Becker-Heidmann and Scharpenseel, 1986; Nadelhoffer and Fry, 1988) and is in accordance with oxic grassland soils (Accoe et al., 2003).

In the upper layers of both grassland sites, depth profiles of $\delta^{13} \mathrm{C}$ values are apparently compressed compared to NW (Fig. 2). A linear regression analysis with $\delta^{13} \mathrm{C}$ vs. depth reveals a tendency towards steepest slopes of $\delta^{13} \mathrm{C}$ vs. depth at GI followed by GE and NW (Table 1). However, we do not regard this pattern as a quantitative indicator. Below the inversion at $-25.0 \%, \delta^{13} \mathrm{C}$ values of all profiles remain more or less constant throughout the deeper profile, indicating low decomposition with limited fractionation (Clymo and Bryant, 2008).

\subsection{Stable nitrogen isotopes}

The $\delta^{15} \mathrm{~N}$ signal in peat soils is mainly driven by the following processes: vegetation input, decomposition, $\mathrm{N}$ deposition and fertilizer application. The $\delta^{15} \mathrm{~N}$ values of a natural bog should be constant at around $0.0 \%$ because atmospheric $\mathrm{N}$ is the primary source of $\mathrm{N}$ (Jones et al., 2010; Broder et al., 2012).
Table 1. Slope, depth and coefficient of determination of regression analyses between $\delta^{13} \mathrm{C}$ and depth until a $\delta^{13} \mathrm{C}$ value of $-25.0 \%$ o was reached in the depth profile. Three profiles of each site - nearnatural (NW), extensively managed grassland (GE) and intensively managed grassland (GI) site - from the Ahlen-Falkenberger peatland are presented. " $n$ " refers to number of soil segments per site and replication included in the regression.

\begin{tabular}{lrrrrr}
\hline Site/core & Depth $(\mathrm{cm})$ & Slope & $R^{2}$ & $p$ & $n$ \\
\hline NW1 & 25.0 & 0.26 & 0.97 & 0.0004 & 7 \\
NW2 & 65.0 & 0.07 & 0.92 & 0.0000 & 17 \\
NW3 & 65.0 & 0.08 & 0.94 & 0.0000 & 17 \\
GE1 & 23.7 & 0.13 & 0.92 & 0.0023 & 6 \\
GE2 & 40.3 & 0.09 & 0.74 & 0.0015 & 10 \\
GE3 & 31.7 & 0.11 & 0.92 & 0.0022 & 6 \\
GI1 & 28.4 & 0.21 & 0.96 & 0.0008 & 6 \\
GI2 & 31.0 & 0.14 & 0.89 & 0.0016 & 7 \\
GI3 & 18.7 & 0.20 & 0.90 & 0.0146 & 5 \\
\hline
\end{tabular}

At NW the $\delta^{15} \mathrm{~N}$ values first increase and then decrease with depth (Fig. 3a). The inversion is located at ca. $20-40 \mathrm{~cm}$ depth, corresponding to $\delta^{15} \mathrm{~N}$ values of -2.0 to $-4.0 \%$. At the grassland sites, stable nitrogen isotopes decrease with depth in the first $20 \mathrm{~cm}$ of the soil and with no further clear trend in the deeper parts of the profile. In the first few centimetres of the GE profile, $\delta^{15} \mathrm{~N}$ values are slightly positive and reach values of around $-4.0 \%$ below $20 \mathrm{~cm}$ (Fig. 3b). At GI $\delta^{15} \mathrm{~N}$ values are positive in the uppermost centimetres (up to $4.0 \%$ ) and decrease down to $-10.5 \%$ in deeper layers (Fig. 3c). Compared to GE $\delta^{15} \mathrm{~N}$ is more variable at GI and reaches more negative values in the deeper part of the soil profile.

In natural peatlands, like NW, peat plant species show a wide range of $\delta^{15} \mathrm{~N}$ values from below -11.0 to above $+2.0 \%$ (Asada et al., 2005b), which may influence the $\delta^{15} \mathrm{~N}$ values of the remaining peat material in the profile. The $\delta^{15} \mathrm{~N}$ depletion in the upper part of NW profiles may be assignable to the very low $\delta^{15} \mathrm{~N}$ values of the vegetation (Nordbakken et al., 2003; Bragazza et al., 2010). Sphagnum mosses are depleted in ${ }^{15} \mathrm{~N}$ compared to atmospheric nitrogen and have even lower $\delta^{15} \mathrm{~N}$ values in areas affected by agricultural activities (Bragazza et al., 2005). Incubation of peat mosses has shown a ${ }^{15} \mathrm{~N}$ enrichment with time resulting in an increase in $\delta^{15} \mathrm{~N}$ values with depth in the near surface (Asada et al., 2005a). Below approximately $20 \mathrm{~cm}, \delta^{15} \mathrm{~N}$ values are less negative and in the range of nitrogen isotope values typical for mosses (Asada et al., 2005b). Human activities greatly influence $\delta{ }^{15} \mathrm{~N}$ values in mosses beyond triggering decomposition via atmospheric $\mathrm{N}$ depositions. The various $\mathrm{N}$ sources vary in their isotopic signature (Bragazza et al., 2005). Low $\delta^{15} \mathrm{~N}$ values were reported in areas with high local ammonia emissions (from livestock during animal husbandry, manure storage and spreading; Asman et al., 1998), owing to the 


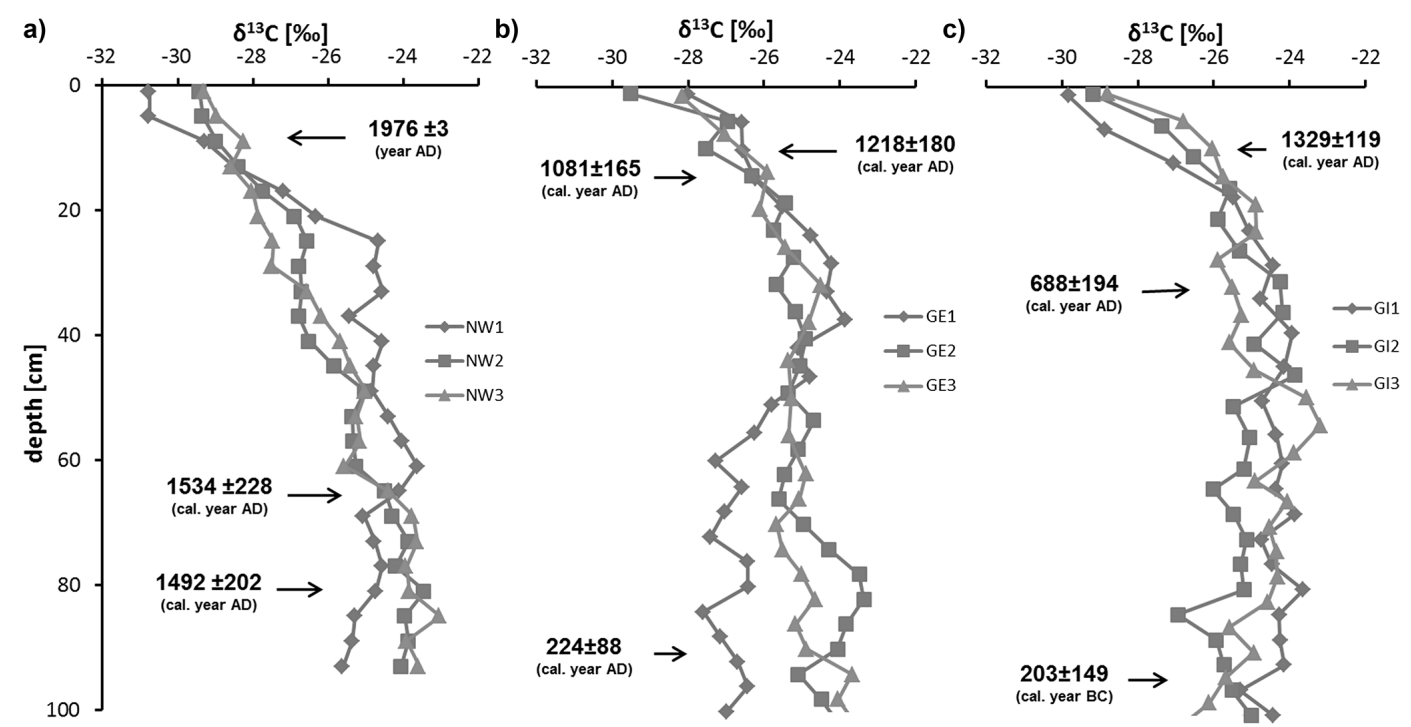

Figure 2. $\delta^{13} \mathrm{C}$ depth profiles at (a) the near-natural site (NW), (b) extensively used grassland site (GE) and (c) intensively used grassland site (GI) at the Ahlen-Falkenberger peatland. Calibrated radiocarbon ages are displayed as mean calendar ages with 1 standard deviation $(n=3)$ at their corresponding depth.
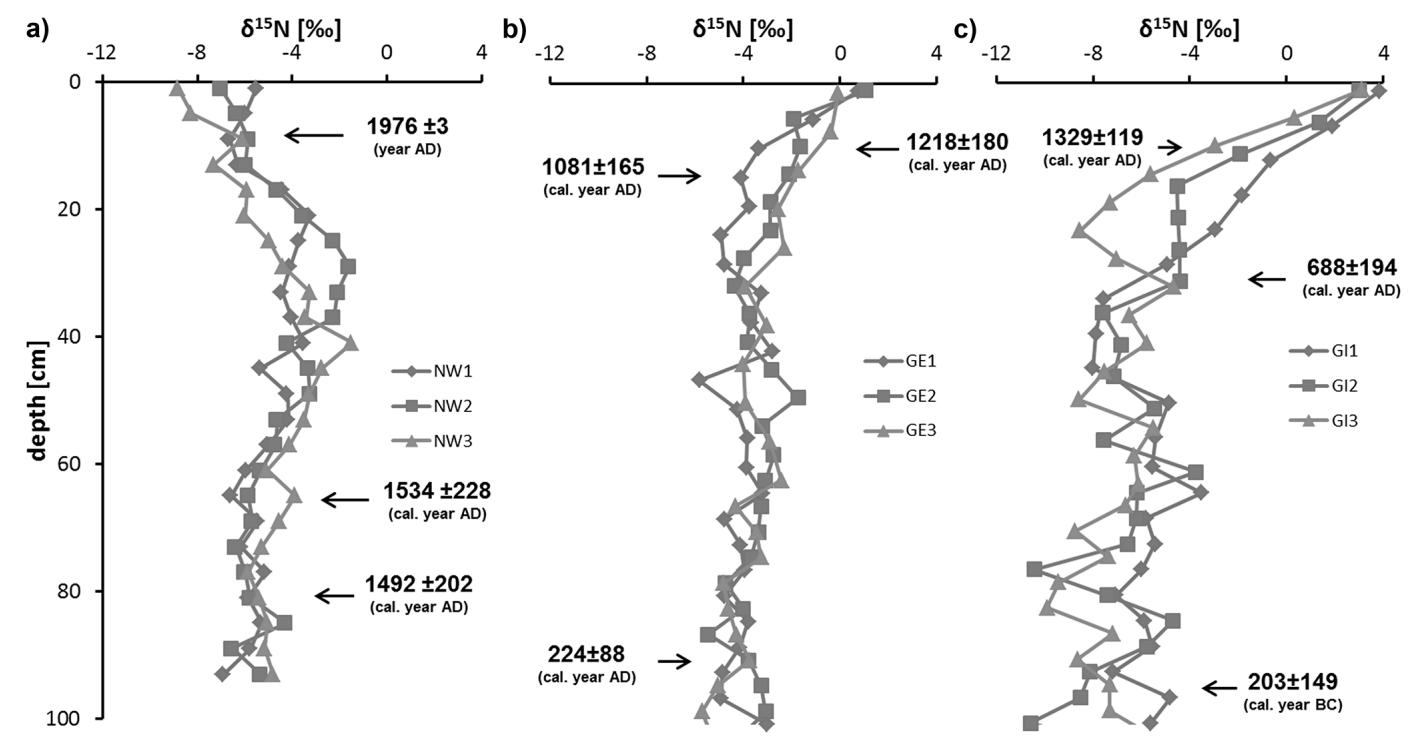

Figure 3. $\delta^{15} \mathrm{~N}$ depth profiles at (a) the near-natural site (NW), (b) extensively used grassland site (GE) and (c) intensively used grassland site (GI) at the Ahlen-Falkenberger peatland. Calibrated radiocarbon ages are displayed as mean calendar ages with 1 standard deviation $(n=3)$ at their corresponding depth.

very low $\delta^{15} \mathrm{~N}$ values in wet $\left(\mathrm{NH}_{4}\right)$ and dry $\left(\mathrm{NH}_{3}\right)$ deposition (Bragazza et al., 2005).

$\delta^{15} \mathrm{~N}$ depth profiles of our drained sites show a completely different depth pattern as hypothesized in our theoretical concept for drained peatlands (Fig. 1) and decrease rather than increase with depth (Fig. 3). High $\delta^{15} \mathrm{~N}$ of the topsoil in our grassland sites (Fig. 3) most likely indicates increased microbial activity, caused by drainage, in conjunction with effects from organic fertilizer application at GI. Decomposition is often linked to an enrichment of ${ }^{15} \mathrm{~N}$ because of the prefer- ential use of ${ }^{14} \mathrm{~N}$ (Högberg, 1997; Novak et al., 1999; Kalbitz et al., 2000). Increased microbial activity in the first centimetres of the drained peatland leads to increased turnover of $\mathrm{N}$, which results in an enrichment of ${ }^{15} \mathrm{~N}$ (Kalbitz et al., 2000), especially in the first $2-5 \mathrm{~cm}$. It can therefore be postulated that the decomposition of peat material results in an enrichment of ${ }^{15} \mathrm{~N}$. This is one possible explanation for the higher $\delta^{15} \mathrm{~N}$ values at GE and GI as compared to NW. Atmospheric $\mathrm{N}$ deposition, as discussed above, could additionally influence the $\delta^{15} \mathrm{~N}$ signal in these profiles; however, we do not see 
Table 2. Correlation coefficient and $p$ value ( $p<0.05$ in boldface) between $\delta^{13} \mathrm{C}$ and $\mathrm{C} / \mathrm{N}$ ratio as well as between $\delta^{15} \mathrm{~N}$ and $\mathrm{C} / \mathrm{N}$ ratio for the whole profile at the near-natural (NW), extensively managed grassland (GE) and intensively managed grassland (GI) sites at the Ahlen-Falkenberger peatland.

\begin{tabular}{lll}
\hline Site/core & $\delta^{13}$ C vs. C / N & $\delta^{15} \mathrm{~N}$ vs. C / N \\
\hline NW 1 & $0.40^{(0.051)}$ & $-0.41^{(0.051)}$ \\
NW 2 & $0.60^{(\mathbf{0 . 0 0 2})}$ & $-0.52^{(\mathbf{0 . 0 1 0})}$ \\
NW 3 & $0.46^{(\mathbf{0 . 0 2 2})}$ & $-0.49^{(\mathbf{0 . 0 1 6})}$ \\
GE 1 & $0.49^{(\mathbf{0 . 0 1 2})}$ & $-0.81^{(\mathbf{0 . 0 0 0})}$ \\
GE 2 & $0.70^{(\mathbf{0 . 0 0 0})}$ & $-0.85^{(\mathbf{0 . 0 0 0})}$ \\
GE 3 & $0.32^{(\mathbf{0 . 0 0 0})}$ & $-0.74^{(\mathbf{0 . 0 0 2})}$ \\
GI 1 & $0.61^{(\mathbf{0 . 0 0 2})}$ & $-0.78^{(\mathbf{0 . 0 0 0})}$ \\
GI 2 & $0.68^{(\mathbf{0 . 0 0 0})}$ & $-0.75^{(\mathbf{0 . 0 0 0})}$ \\
GI 3 & $0.32^{(0.109)}$ & $-0.74^{(\mathbf{0 . 0 0 0})}$ \\
\hline
\end{tabular}

any effect at site NW. Organic fertilizer may also be enriched in ${ }^{15} \mathrm{~N}$ (Watzka et al., 2006), which may contribute to higher $\delta^{15} \mathrm{~N}$ values in the topsoil of GI. A study of nitrogen isotopes from mineral and organic fertilizer demonstrated that organic fertilizer has a mean $\delta^{15} \mathrm{~N}$ value of $+8.5 \%$ (Bateman and Kelly, 2007). However, GE, which does not receive any fertilizer, is also enriched in ${ }^{15} \mathrm{~N}$ in the first centimetres of the profile. We therefore assign the (smaller) ${ }^{15} \mathrm{~N}$ enrichment at GE to ongoing oxidative peat decomposition and the (stronger) ${ }^{15} \mathrm{~N}$ enrichment at GI to the combined effect of peat decomposition and organic fertilizer applications.

\subsection{Radiocarbon ages}

Radiocarbon signatures from the upper peat layers $(8-10 \mathrm{~cm}$ depth) of site NW indicate the presence of bomb carbon and organic matter fixed during the second half of the last century. This recent $\mathrm{C}$ accumulation of almost $1.0 \mathrm{~kg} \mathrm{C} \mathrm{m}^{-2}$ in approximately the last 50 years at $\mathrm{NW}$ is in accordance with the current GHG flux measurements (Beetz et al., 2013), showing that the bog has been sequestering carbon during recent years. In deeper parts (65-81 cm depth) of NW, mean peat ages range between 1328 and $1796 \mathrm{cal}$ years AD. The small differences between the mean radiocarbon ages at 65 and $81 \mathrm{~cm}$ depth at NW represent an indicator for undisturbed peat. They point to an average $16 \mathrm{~cm}$ of peat growth in approximately 62 years.

At both grassland sites, calibrated radiocarbon ages in the upper centimetres are much higher than at NW. This finding can be taken as an indicator for peat degradation and carbon loss. Drainage-induced carbon loss starts from the top, selectively removing younger peat and exposing older peat to the surface. We found $>500$-year-old peat in the upper $14 \mathrm{~cm}$ at these sites. At 14 to $19 \mathrm{~cm}$ depth at GE and 27 to $34 \mathrm{~cm}$ depth at GI, the peat is almost 1000 and 1300 years old, respectively. Peat in deeper parts of the grassland profiles shows calibrated mean ages of 165 to $325 \mathrm{cal}$ years $\mathrm{AD}$ and 313 to
34 cal years BC at GE and GI, respectively. The higher ages in the upper parts of the profile at GI indicate higher peat and $\mathrm{C}$ losses compared to the GE, when similar conditions in the peat profiles before onset of drainage are assumed. In comparison to NW, peat in deeper parts of the two grassland sites is up to 1500 years older. The grassland sites have lost almost all peat that has accumulated in the last several centuries.

\section{$3.4 \mathrm{C} / \mathrm{N}$ ratio}

At both grassland sites, $\mathrm{C} / \mathrm{N}$ ratios are smaller in the upper layers of the soil profile (Fig. S2), indicating strong microbial transformation of the peat (Malmer and Holm, 1984; Kuhry and Vitt, 1996) and the possible influence of fertilization (GI). In most samples from NW and in deeper layers of GI and GE, $\mathrm{C} / \mathrm{N}$ ratios are in the range considered typical for ombrotrophic peatlands (Kuhry and Vitt, 1996) and indicate low microbial activity.

\subsection{Correlations between stable isotopes and soil $\mathrm{C} / \mathrm{N}$}

Decomposition affects both stable $\delta^{13} \mathrm{C}$ and $\delta^{15} \mathrm{~N}$ by an enrichment of the heavier isotopes in the remaining soil organic matter as well as decreasing $\mathrm{C} / \mathrm{N}$ ratio. A linear correlation between these parameters is expected if the material is influenced by strong decomposition during peat formation or post-sedimentation (Wynn, 2007; Engel et al., 2010). However, no correlation between the above-mentioned parameters will be found in well-preserved peat (Engel et al., 2010; Jones et al., 2010).

Stable isotopes and the $\mathrm{C} / \mathrm{N}$ ratio correlate in a weakly positive way ( $r=0.40$ to 0.60$)$ and a weakly negative way $(r=-0.41$ to -0.52$)$ at $\mathrm{NW}$ for $\delta^{13} \mathrm{C}$ and $\delta^{15} \mathrm{~N}$, respectively (see Table 2), indicating that the peat is not strongly decomposed and/or that decomposition did not alter the original isotope signal (Sharma et al., 2005). Zaccone et al. (2011) also found a positive, albeit not significant correlation between $\delta^{13} \mathrm{C}$ and $\mathrm{C} / \mathrm{N}$ in a well-preserved peat bog in the Swiss Jura mountains. At our grassland sites, $\delta^{13} \mathrm{C}$ and the $\mathrm{C} / \mathrm{N}$ ratio correlate positively ( $r=0.32$ to 0.70$)$, and $\delta^{15} \mathrm{~N}$ and the $\mathrm{C} / \mathrm{N}$ ratio correlate negatively $(r=-0.74$ to -0.85$)$, indicating that the peat is strongly decomposed.

\subsection{Ash content and bulk density}

Ash content and bulk density are indicators of peat decomposition (Clymo, 1984). At NW, ash content is enriched between 10 and $60 \mathrm{~cm}$ depth at NW (Fig. 4a). Bulk density increases at this depth and is higher compared to deeper parts of the profiles (Fig. S3). A higher ash content in these depths compared to the deeper layers suggests an increase in the decomposition of the peat (Engel et al., 2010). We interpret this ash accumulation as being the result of drainage activities in the vicinity of NW during the formation of these peat layers. The peat layers with the enriched ash content at the NW site are on average between 50 and 500 years old, which corre- 


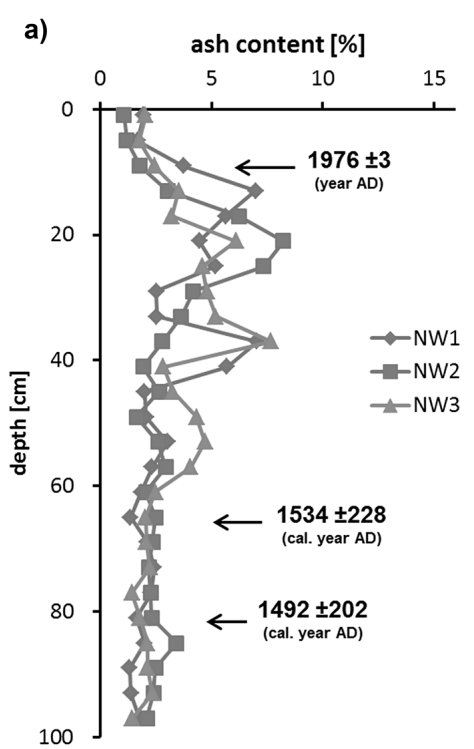

b)
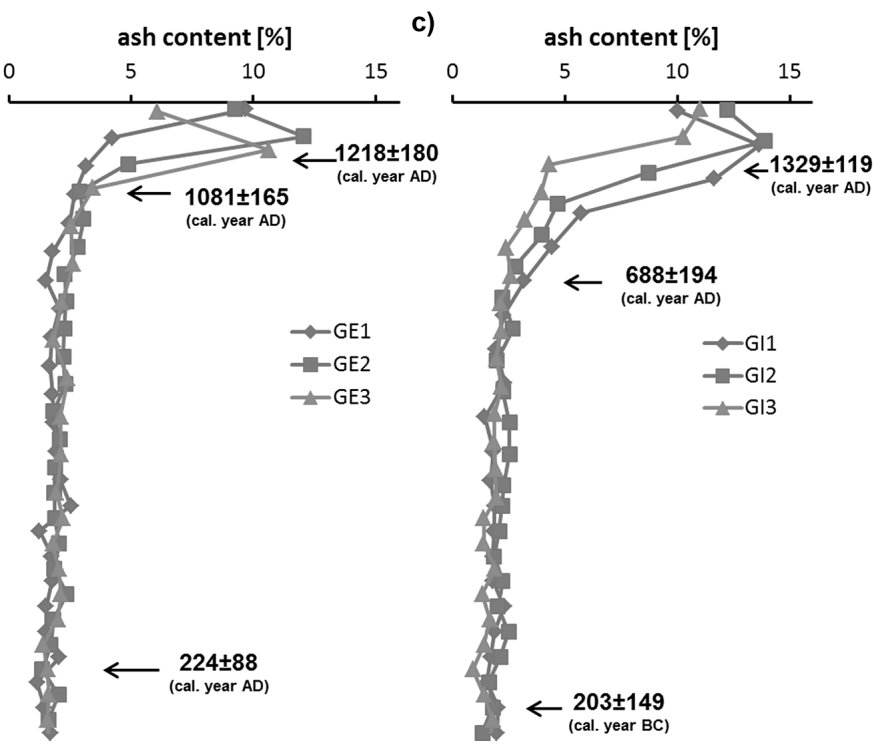

Figure 4. Ash content depth profiles at (a) the near-natural site (NW), (b) extensively used grassland site (GE) and (c) intensively used grassland site (GI) at the Ahlen-Falkenberger peatland. Calibrated radiocarbon ages are displayed as mean calendar ages with 1 standard deviation $(n=3)$ at their corresponding depth.

Table 3. Biogeochemical parameters from the Ahlen-Falkenberger peatland profiles as indicators of peatland degradation as well as peat and carbon loss.

\begin{tabular}{lll}
\hline Parameters & $\begin{array}{l}\text { Reliable indicator } \\
\text { for peat degradation? }\end{array}$ & $\begin{array}{l}\text { Quantification of } \\
\text { C loss possible? }\end{array}$ \\
\hline$\delta^{13} \mathrm{C}$ & yes & no \\
$\delta^{15} \mathrm{~N}$ & yes & no \\
Ash content & yes* & yes \\
${ }^{14} \mathrm{C}$ age & yes & (yes) \\
$\mathrm{C} / \mathrm{N}$ & (yes) & no \\
Bulk density & (yes) & (yes with ash content) \\
Correlation between $\delta^{13} \mathrm{C}$, & yes & no \\
$\delta^{15} \mathrm{~N}$ and $\mathrm{C} / \mathrm{N}$ & & \\
\hline
\end{tabular}

* For bogs and assuming homogeneous atmospheric input.

sponds to the beginning of the first land use intensification in this peatland. Above and below this depth, the ash content is small, indicating less decomposed peat. High ash contents (Fig. 4b, c) and bulk densities (Fig. S3) in the first centimetres of the profile at both grassland sites indicate peatland degradation and refer to recent and ongoing peat oxidation. In deeper layers of GE and GI, ash contents are constant and very low (Fig. 4) and are in the range of natural peatlands (Clymo, 1984) and also of deeper, undisturbed layers at NW.

\subsection{Carbon loss}

Carbon losses estimated by the combined method are highest at GI, intermediate at GE and lowest at NW. The mean $( \pm \mathrm{SD}) \mathrm{C}$ losses are $11.5( \pm 6.3), 18.8( \pm 2.8)$ and 42.9 $( \pm 10.9) \mathrm{kg} \mathrm{C} \mathrm{m}^{-2}$ for NW, GE and GI, respectively. The C loss at site NW may be attributed to the intensive drainage and peat extraction activities in the surrounding area in the last century, which may also have impaired the hydrology of this remaining bog. However, in recent years/decades, peat at NW has been accumulating $\mathrm{C}$ again (Beetz et al., 2013) and can therefore today be considered as a $\mathrm{C}$ sink. This is attributed to the current restoration activity within the context of the designation of a nature conservation area at this site with an accompanying increase in the water table (Beckmann and Krahn, 1991; Beller et al., 1994). The heath vegetation at $\mathrm{NW}$, as is common for peat bogs in Germany, suggests a mild degradational stage (Ellenberg, 1954) with likely historical anthropogenic influences. The carbon loss of the grassland sites determined in this study is in accordance with higher measured GHG emissions at site GI than at site GE (Beetz et al., 2013). In general, the net GHG emission from extensively managed grasslands is smaller than from intensively managed grasslands, owing to a combination of smaller $\mathrm{C}$ exports and higher water tables (Drösler et al., 2013). The total carbon loss at these sites since the onset of drainage is comparable to drained peatlands in Switzerland under extensive management (Leifeld et al., 2011a).

\subsection{Indicators of peatland degradation and quantification of $\mathrm{C}$ loss}

All parameters $\left(\delta^{13} \mathrm{C}, \delta^{15} \mathrm{~N}\right.$, ash content, $\mathrm{C} / \mathrm{N}$ ratio, bulk density and radiocarbon ages) indicate a degradation of the former bog at the Ahlen-Falkenberger peatland when managed as grassland (GE and GI). All of these parameters might be useful indicators of peatland degradation but not all can be used in a quantitative manner (Table 3). 
Stable carbon isotope depth profiles indicate degradation at all sites at the peatland. At NW in the upper $10 \mathrm{~cm}$ and below $65 \mathrm{~cm}$ depth as well as in deeper parts of the grassland sites, $\delta^{13} \mathrm{C}$ is constant with depth indicating natural peat. Stable nitrogen isotope, ash content and C / N ratio as well as bulk density depth profiles show a higher decomposition of the peat material in the upper part at the grassland sites as well as at $20-60 \mathrm{~cm}$ depth at NW. The $\delta^{15} \mathrm{~N}$ signal in the peat profiles is mainly driven by decomposition (GE and GI) and fertilizer application (GI). Radiocarbon ages and $\delta^{13} \mathrm{C}$ as well as ash content in the first centimetre of the NW depth profiles provide evidence for contemporary peat accumulation with young peat material formed in the last decades. Peat from topsoil segments of both grassland sites is much older than peat from deeper segments of the NW site. These data illustrate the consequences of peatland drainage that induces the loss of peat material which has been accumulated over the last centuries. The ash content in combination with bulk density and $\mathrm{C}$ content (combined method) gives reasonable estimates of $\mathrm{C}$ loss since the onset of drainage activities in this peatland.

Soil ash content and radiocarbon signatures have the potential to provide quantitative estimates of peatland carbon loss, whereas changes in stable isotope patterns and $\mathrm{C} / \mathrm{N}$ ratios serve as qualitative indicators and support the understanding of processes and mechanisms involved.

\section{Conclusions}

Depth profiles of different biogeochemical parameters together provide a detailed insight into peatland formation and the effects of management on peat degradation. $\delta^{13} \mathrm{C}, \delta^{15} \mathrm{~N}$, ash content, $\mathrm{C} / \mathrm{N}$ ratio and bulk density as well as radiocarbon ages in peat depth profiles indicate degradation of all peatlands, but to very different degrees. Peat and C loss could be quantified by the combination of ash content and bulk density and is supported by the radiocarbon ages.

I. Increasing $\delta^{13} \mathrm{C}$ values with depth indicate aerobic decomposition of the peat material at all sites.

II. At the near-natural site (NW), stable carbon isotope and ash content depth profiles as well as radiocarbon dating indicate moderate degradation due to the drainage of the surrounding area in the past. Hence, also bogs considered semi-natural were impaired by anthropogenic activities. Recent organic-matter accumulation, as indicated by the ${ }^{14} \mathrm{C}$ values, indicates the rehabilitation of the peatland.

III. With the conversion to grassland, increasing peat decomposition and fertilizer application systematically alter the $\delta^{15} \mathrm{~N}$ signature of the soil.

IV. Based on ash accumulation calculations, the three sites lost carbon in the following order: $\mathrm{NW}<\mathrm{GE}<\mathrm{GI}$.
Higher losses under intensive management are supported by (i) higher peat ages at this site and (ii) steeper slopes of $\delta^{13} \mathrm{C}$ depth profiles.

\section{The Supplement related to this article is available online at doi:10.5194/bg-12-2861-2015-supplement.}

Acknowledgements. We would like to thank Sascha Beetz and Katharina Krüger for support during field work. Thanks to Mark Rollog and Axel Birkholz for stable isotope analyses and Martin Zuber for ash content analyses. This work was supported financially by the Swiss National Science Foundation (SNF), project no. 200021-137569.

Edited by: Y. Kuzyakov

\section{References}

Accoe, F., Boeckx, P., Van Cleemput, O., and Hofman, G.: Relationship between soil organic $\mathrm{C}$ degradability and the evolution of the delta13C signature in profiles under permanent grassland, Rapid Commun. Mass Sp., 17, 2591-2596, doi:10.1002/rcm.1202, 2003.

Ågren, G. I., Bosatta, E., and Balesdent, J.: Isotope discrimination during decomposition of organic matter: A theoretical analysis, Soil Sci. Soc. Am. J., 60, 1121-1126, 1996.

Ahrendt, R.: Die Entdeckung des Ahlenmoores - Aneignungen einer Landschaft in der ersten Hälfte des 20. Jahrhunderts, Beiträge zur Geschichte und Kultur des Elbe-Weser-Raumes, Verlag des Landschaftsverband der ehemaligen Herzogtümer Bremen und Verden, Stade, 2012.

Alewell, C., Giesler, R., Klaminder, J., Leifeld, J., and Rollog, M.: Stable carbon isotopes as indicators for environmental change in palsa peats, Biogeosciences, 8, 1769-1778, doi:10.5194/bg-81769-2011, 2011.

Asada, T., Warner, B., and Aravena, R.: Effects of the early stage of decomposition on change in carbon and nitrogen isotopes in Sphagnumlitter, Journal of Plant Interactions, 1, 229-237, doi:10.1080/17429140601056766, 2005a.

Asada, T., Warner, B. G., and Aravena, R.: Nitrogen isotope signature variability in plant species from open peatland, Aquat. Bot., 82, 297-307, doi:10.1016/j.aquabot.2005.05.005, 2005b.

Asman, W. A. H., Sutton, M. A., and Schjørring, J. K.: Ammonia: emission, atmospheric transport and deposition, New Phytol., 139, 27-48, 1998.

Bateman, A. S. and Kelly, S. D.: Fertilizer nitrogen isotope signatures, Isot. Environ. Health S., 43, 237-247, doi:10.1080/10256010701550732, 2007.

Becker-Heidmann, P. and Scharpenseel, H. W.: Thin layer $\delta^{13} \mathrm{C}$ and $\delta^{14} \mathrm{C}$ monitoring of "lessive" soil profiles, Radiocarbon, 28, 383390, 1986.

Beckmann, M. and Krahn, B.: Pflege- und Entwicklungskonzept Ahlen-Falkenberger Moor, BR Lüneburg, BUND-AGNL, Wagenfeld, 1991. 
Beetz, S., Liebersbach, H., Glatzel, S., Jurasinski, G., Buczko, U., and Höper, H.: Effects of land use intensity on the full greenhouse gas balance in an Atlantic peat bog, Biogeosciences, 10, 1067-1082, doi:10.5194/bg-10-1067-2013, 2013.

Beller, J., Buchwald, C., and Döringshoff, J.: Pflege- und Entwicklungsplan Halemer See und Dahlemer See mit Randzonen, Endbericht, edited by: BR Lüneburg AG,, Freiburg, 1994.

Benner, R., Fogel, M. L., Sprague, E. K., and Hodson, R. E.: Depletion of 13-C in lignin and its implications for stable carbon isotope studies, Nature, 329, 708-710, 1987.

Bragazza, L., Limpens, J., Gerdol, R., Grosvernier, P., Hajek, M., Hajek, T., Hajkova, P., Hansen, I., Iacumin, P., Kutnar, L., Rydin, H., and Tahvanainen, T.: Nitrogen concentration and delta $15 \mathrm{~N}$ signature of ombrotrophic Sphagnum mosses at different $\mathrm{N}$ deposition levels in Europe, Glob. Change Biol., 11, 106-114, doi:10.1111/j.1365-2486.2004.00886.x, 2005.

Bragazza, L., Iacumin, P., Siffi, C., and Gerdol, R.: Seasonal variation in nitrogen isotopic composition of bog plant litter during 3 years of field decomposition, Biol. Fert. Soils, 46, 877-881, doi:10.1007/s00374-010-0483-7, 2010.

Broder, T., Blodau, C., Biester, H., and Knorr, K. H.: Peat decomposition records in three pristine ombrotrophic bogs in southern Patagonia, Biogeosciences, 9, 1479-1491, doi:10.5194/bg9-1479-2012, 2012.

Byrne, K. A., Chojnicki, B., Christensen, T. R., Drösler, M., Freibauer, A., Frolking, S., Lindroth, A., Mailhammer, J., Malmer, N., Selin, P., Turunen, J., Valentini, R., and Zetterberg, L.: EU Peatlands: current carbon stocks and trace gas fluxes, Department of Forest Science and Environment, Viterbo, Italy, 158, 2004.

Clymo, R.: The limits to peat bog growth, Philos. T. R. Soc. B, 303, 605-654, 1984.

Clymo, R. S. and Bryant, C. L.: Diffusion and mass flow of dissolved carbon dioxide, methane, and dissolved organic carbon in a 7-m deep raised peat bog, Geochim. Cosmochim. Ac., 72, 2048-2066, doi:10.1016/j.gca.2008.01.032, 2008

Conen, F., Yakutin, M. V., Carle, N., and Alewell, C.: delta15N natural abundance may directly disclose perturbed soil when related to C:N ratio, Rapid Commun. Mass Sp., 27, 1101-1104, doi:10.1002/rcm.6552, 2013.

Drösler, M., Freibauer, A., Christensen, T. R., and Friborg, T.: Observations and Status of Peatland Greenhouse Gas Emissions in Europe, in: The Continental-Scale Greenhouse Gas Balance of Europe, edited by: Dolman, J., Valentini, R., and Freibauer, A., Springer, New York, 243-261, 2008.

Drösler, M., Adelmann, W., Augustin, J., Bergman, L., Beyer, C., Chojnicki, B., Förster, C., Freibauer, A., Giebels, M., Görlitz, S., Höper, H., Kantelhardt, J., Liebersbach, H., Hahn-Schöfl, M., Minke, M., Petschow, U., Pfadenhauer, J., Schaller, L., Schägner, P., Sommer, M., Thuille, A., and Werhan, M.: Klimaschutz durch Moorschutz, Schlussbericht des Vorhabens "Klimaschutz - Moornutzunsstrategien” 2006-2010, Freisingen, 2013.

Ellenberg, H.: Naturgemäße Anbauplanung, Melioration und Landespflege. Landwirtschaftliche Pflanzensoziologie III, Stuttgart, 109 pp., 1954.

Engel, Z., Skrzypek, G., Paul, D., Drzewicki, W., and Nývlt, D.: Sediment lithology and stable isotope composition of organic matter in a core from a cirque in the Krkonoše Mountains, Czech
Republic, J. Paleolimnol., 43, 609-624, doi:10.1007/s10933009-9356-1, 2010.

Ewing, J. M. and Vepraskas, M. J.: Estimating primary and secondary subsidence in an organic soil 15, 20, and 30 years after drainage, Wetlands, 26, 119-130, 2006.

Frank, S., Tiemeyer, B., Gelbrecht, J., and Freibauer, A.: High soil solution carbon and nitrogen concentrations in a drained Atlantic bog are reduced to natural levels by 10 years of rewetting, Biogeosciences, 11, 2309-2324, doi:10.5194/bg-11-2309-2014, 2014.

Grønlund, A., Hauge, A., Hovde, A., and Rasse, D. P.: Carbon loss estimates from cultivated peat soils in Norway: a comparison of three methods, Nutr. Cycl. Agroecosys., 81, 157-167, doi:10.1007/s10705-008-9171-5, 2008.

Högberg, P.: Tansley review No 95 - N-15 natural abundance in soil-plant systems, New Phytol., 137, 179-203, doi:10.1046/j.1469-8137.1997.00808.x, 1997.

Höper, H.: Freisetzung von Treibhausgasen aus deutschen Mooren, TELMA, 37, 85-116, 2007.

Hua, Q., Barbetti, M., and Rakowski, A. Z.: Atmospheric radiocarbon for the period 1950-2010, Radiocarbon, 55, 2059-2072, 2013.

IPCC: 2013 Supplement to the 2006 IPCC Guidlines for National Greenhosue Gas Inventories: Wetlands, 2013.

Jones, M. C., Peteet, D. M., and Sambrotto, R.: Late-glacial and Holocene $\delta 15 \mathrm{~N}$ and $\delta 13 \mathrm{C}$ variation from a Kenai Peninsula, Alaska peatland, Palaeogeography, Palaeoclimatology, Palaeoecology, 293, 132-143, doi:10.1016/j.palaeo.2010.05.007, 2010.

Jungkunst, H. F., Krüger, J. P., Heitkamp, F., Erasmi, S., Fiedler, S., Glatzel, S., and Lal, R.: Accounting more precisely for peat and other soil carbon resources, in: Recarbonization of the biosphere - ecosystems and the global carbon cycle, edited by: Lal, R., Lorenz, K., Hüttl, R. F. J., Schneider, B. U., and von Braun, J., Springer, Amsterdam, Netherlands, 127-157, 2012.

Kalbitz, K., Geyer, S., and Gehre, M.: Land use impacts on the isotopic signature $(\mathrm{C}-13, \mathrm{C}-14, \mathrm{~N}-15)$ of water-soluble fulvic acids in a German fen area, Soil Sci., 165, 728-736, doi:10.1097/00010694-200009000-00006, 2000.

Kohzu, A., Matsui, K., Yamada, T., Sugimoto, A., and Fujita, N.: Significance of rooting depth in mire plants: evidence from natural 15N abundance, Ecol. Res., 18, 257-266, 2003.

Krüger, J. P., Leifeld, J., and Alewell, C.: Degradation changes stable carbon isotope depth profiles in palsa peatlands, Biogeosciences, 11, 3369-3380, doi:10.5194/bg-11-3369-2014, 2014.

Krull, E. S. and Retallack, G. J.: $\delta 13 \mathrm{C}$ depth profiles from paleosols across the Permian-Triassic boundary: Evidence for methane release, Geol. Soc. Am. Bull., 112, 1459-1472, 2000.

Kuhry, P. and Vitt, D. H.: Fossil carbon/nitrogen ratios as a measure of peat decomposition, Ecology, 77, 271-275, 1996.

Leifeld, J., Gubler, L., and Grünig, A.: Organic matter losses from temperate ombrotrophic peatlands: an evaluation of the ash residue method, Plant Soil, 341, 349-361, doi:10.1007/s11104010-0649-y, 2011a.

Leifeld, J., Müller, M., and Fuhrer, J.: Peatland subsidence and carbon loss from drained temperate fens, Soil Use Manage., 27, 170-176, doi:10.1111/j.1475-2743.2011.00327.x, 2011b.

Leifeld, J., Bader, C., Borraz, E., Hoffmann, M., Giebels, M., Sommer, M., and Augustin, J.: Are C-loss rates from drained peatlands constant over time? The additive value of soil profile based 
and flux budget approach, Biogeosciences Discuss., 11, 1234112373, doi:10.5194/bgd-11-12341-2014, 2014.

Maljanen, M., Hytonen, J., and Martikainen, P. J.: Fluxes of $\mathrm{N}_{2} \mathrm{O}$, $\mathrm{CH}_{4}$ and $\mathrm{CO}_{2}$ on afforested boreal agricultural soils, Plant Soil, 231, 113-121, doi:10.1023/a:1010372914805, 2001.

Malmer, N. and Holm, E.: Variation in the $\mathrm{C} / \mathrm{N}$-quotient of peat in relation to decomposition rate and age determination with 210 $\mathrm{Pb}$, Oikos, 171-182, 1984.

Meusburger, K., Mabit, L., Park, J.-H., Sandor, T., and Alewell, C.: Combined use of stable isotopes and fallout radionuclides as soil erosion indicators in a forested mountain site, South Korea, Biogeosciences, 10, 5627-5638, doi:10.5194/bg-10-5627-2013, 2013.

Nadelhoffer, K., Shaver, G., Fry, B., Giblin, A., Johnson, L., and McKane, R.: $15 \mathrm{~N}$ natural abundances and $\mathrm{N}$ use by tundra plants, Oecologia, 107, 386-394, 1996.

Nadelhoffer, K. J. and Fry, B.: Controls on Natural Nitrogen-15 and Carbon-13 Abundances in Forest Soil Organic Matter, Soil Sci. Soc. Am. J., 52, 1633-1640, doi:10.2136/sssaj1988.03615995005200060024x, 1988.

Nemec, M., Wacker, L., and Gaggeler, H.: Optimization of the graphitization process at AGE-1, Radiocarbon, 52, 1380-1393, 2010.

Nordbakken, J., Ohlsen, M., and Högberg, P.: Boreal bog plants: nitrogen sources and uptake of recently deposited nitrogen, Environ. Pollut., 126, 191-200, doi:10.1016/s0269-7491(03)001945, 2003.

Novak, M., Buzek, F., and Adamova, M.: Vertical trends in $\delta 13 \mathrm{C}, \delta 15 \mathrm{~N}$ and $\delta 34 \mathrm{~S}$ ratios in bulk Sphagnum peat, Soil Biol. Biochem., 31, 1343-1346, 1999.

Reimer, P. J., Bard, E., Bayliss, A., Beck, J. W., Blackwell, P. G., Ramsey, C. B., Buck, C. E., Cheng, H., Edwards, R. L., Friedrich, M., Grootes, P. M., Guilderson, T. P., Haflidason, H., Hajdas, I., Hatte, C., Heaton, T. J., Hoffmann, D. L., Hogg, A. G., Hughen, K. A., Kaiser, K. F., Kromer, B., Manning, S. W., Niu, M., Reimer, R. W., Richards, D. A., Scott, E. M., Southon, J. R., Staff, R. A., Turney, C. S. M., and van der Plicht, J.: Intcal13 and Marine13 radiocarbon age calibration curves 0-50 000 years cal BP, Radiocarbon, 55, 1869-1887, 2013.

Rogiers, N., Conen, F., Furger, M., Stöckli, R., and Eugster, W.: Impact of past and present land-management on the C-balance of a grassland in the Swiss Alps, Glob. Change Biol., 14, 26132625, doi:10.1111/j.1365-2486.2008.01680.x, 2008.

Schaub, M. and Alewell, C.: Stable carbon isotopes as an indicator for soil degradation in an alpine environment (Urseren Valley, Switzerland), Rapid Commun. Mass Sp., 23, 1499-1507, doi:10.1002/rcm.4030, 2009.
Schneekloth, H.: Das Ahlen-Falkenberger Moor - eine moorgeologische Studie mit Beiträgen zur Altersfrage des Schwarz/Weißtorfkontaktes und zur Stratigraphie des Küstenholozäns, Geologisches Jahrbuch, edited by: Lang, D. H., Hannover, 1970.

Schneekloth, H.: Die Moore in Niedersachsen, in Bereich der Blätter Neumünster, Helgoland Emden und Lingen der Geologischen Karte der Bundesrepublik Deutschland (1:200000), Göttinger Tageblatt, Göttingen, 1981.

Sharma, S., Mora, G., Johnston, J. W., and Thompson, T. A.: Stable isotope ratios in swale sequences of Lake Superior as indicators of climate and lake level fluctuations during the Late Holocene, Quaternary Sci. Rev., 24, 1941-1951, doi:10.1016/j.quascirev.2004.11.009, 2005.

Shotyk, W., Weiss, D., Appleby, P., Cheburkin, A., Frei, R., Gloor, M., Kramers, J., Reese, S., and Van Der Knaap, W.: History of atmospheric lead deposition since 12370 14C yr BP from a peat bog, Jura Mountains, Switzerland, Science, 281, 16351640, 1998.

Skrzypek, G., Paul, D., and Wojtun, B.: Stable isotope composition of plants and peat from Arctic mire and geothermal area in Iceland, Polish Polar Res., 29, 365-376, 2008.

Synal, H.-A., Stocker, M., and Suter, M.: MICADAS: a new compact radiocarbon AMS system, Nuclear Instruments and Methods in Physics Research Section B: Beam Interactions with Materials and Atoms, 259, 7-13, 2007.

Szidat, S., Salazar, G. A., Vogel, E., Battaglia, M., Wacker, L., Synal, H.-A., and Türler, A.: 14C Analysis and Sample Preparation at the New Bern Laboratory for the Analysis of Radiocarbon with AMS (LARA), Radiocarbon, 56, 561-566, doi:10.2458/56.17457, 2014.

Watzka, M., Buchgraber, K., and Wanek, W.: Natural 15N abundance of plants and soils under different management practices in a montane grassland, Soil Biol. Biochem., 38, 1564-1576, doi:10.1016/j.soilbio.2005.11.007, 2006.

Wynn, J. G.: Carbon isotope fractionation during decomposition of organic matter in soils and paleosols: Implications for paleoecological interpretations of paleosols, Palaeogeogr. Palaeoecol., 251, 437-448, doi:10.1016/j.palaeo.2007.04.009, 2007.

Yu, Z., Beilman, D. W., Frolking, S., MacDonald, G. M., Roulet, N. T., Camil, P., and Charman, D. J.: Peatlands an Their Role in the Global Carbon Cycle, EOS, 92, 97-106, 2011.

Zaccone, C., Casiello, G., Longobardi, F., Bragazza, L., Sacco, A., and Miano, T. M.: Evaluating the 'conservative' behavior of stable isotopic ratios $(\delta 13 \mathrm{C}, \delta 15 \mathrm{~N}$, and $\delta 18 \mathrm{O})$ in humic acids and their reliability as paleoenvironmental proxies along a peat sequence, Chem. Geol., 285, 124-132, doi:10.1016/j.chemgeo.2011.03.018, 2011. 